\title{
KNOWLEDGE OF HEALTH PRINCIPLES AMONG PROFESSIONALS IN SLOVENIAN KINDERGARTENS
}

\author{
POZNAVANJE OSNOVNIH ZDRAVSTVENIH UKREPOV MED ZAPOSLENIMI \\ V SLOVENSKIH VRTCIH
}

\author{
Damjan SLABE ${ }^{1}$, Rok FINK¹, Eva DOLENC ${ }^{1 *}$, Andreja KVAS ${ }^{1}$
}

${ }^{1}$ University of Ljubljana, Faculty for Health Sciences, Public Health, Zdravstvena pot 5, 1000 Ljubljana, Slovenia

\section{ABSTRACT}

Keywords: kindergarten teachers, kindergarten teacher assistants, health principles, knowledge
Objectives. Preschool children have significant health issues. From the relevant legislation and regulations, it can be seen that kindergarten teachers (KTs) and kindergarten teacher assistants (KTAs) are expected to be familiarwith the basic hygienic measures and steps for preventing injuries and illnesses, to recognize infectious diseases, and to know how to give the first aid. To gain these skills, a continuous life-long learning is necessary, because the characteristics of diseases are changing. Study design: original research.

Methods. 45 kindergartens in Slovenia were randomly selected and a questionnaire with 17 questions on health themes was sent. An analysis was performed via SPSS 17.0, using descriptive methods and nonparametric $X^{2}$ tests.

Results. There were 774 participants, of whom $56 \%$ were KTs and $44 \%$ KTAs. The share of KTs and KTAs who consider their knowledge of health principles to be very good or excellent is $67 \%$. Their estimation of first aid knowledge is lower. They are also well aware of the importance of health knowledge in their work; a total of $87 \%$ strongly agree with this. The results also show that they are familiar with hygiene principles. The $X^{2}$ test showed there are certain statistically characteristic connections between the age of teachers and their assistants, occupation and work experiences.

Conclusions. Because children are a particularly vulnerable group, teachers can encounter injuries and sudden illnesses at their work. Supplementary education is necessary among skilled workers in educational institutions, including kindergartens.

\section{IZVLEČEK}

Ključne besede: vzgojiteljice, pomočnice vzgojiteljic, zdravstveni ukrepi, znanje
Uvod. Predšolski otroci so ranljiva skupina s specifičnimi zdravstvenimi težavami. Od vzgojiteljic in njihovih pomočnic se zato pričakuje, da imajo znanja o osnovnih higienskih načelih in ukrepih za preprečevanje nastanka bolezni ali poškodb, da prepoznajo nalezljive bolezni in nudijo prvo pomoč v primeru nastanka poškodbe ali nenadnega obolenja. Slednje je tudi zakonsko opredeljeno. Značilnosti bolezni otrok, vrste kroničnih bolezni in smernice ukrepanja $v$ primeru nastanka poškodb ali nenadnih obolenj se spreminjajo. Znanja, ki jih vzgojiteljice in njihove pomočnice usvojijo med šolskim izobraževanjem, naj bi bila le temelj vseživljenjskemu učenju.

Metode. Petinštiridesetim naključno izbranim vrtcem v Sloveniji je bil poslan anketni vprašalnik s 17 vprašanji. $S$ pomočjo programa SPSS 17.0. so bili analizirani pridobljeni podatki, uporabljene so bile opisne metode in neparametrični test $X^{2}$.

Rezultati. $V$ raziskavi je sodelovalo 774 oseb, od tega $56 \%$ vzgojiteljic in $44 \%$ pomočnic vzgojiteljic. Delež tistih, ki so samoocenile svoje znanje o osnovnih higienskih načelih kot zelo dobro ali odlično, je 67-odstoten, 30\% pa je svoje znanje samoocenilo kot dobro. Samoocena znanja prve pomoči je nižja. Največ znanja (skoraj polovico) so anketirani usvojili med izobraževanjem na srednji šoli ali fakulteti. Da je tudi zdravstveno znanje pri delu z otroki zelo pomembno, se močno strinja $87 \%$ anketiranih in strinja 13\%. Rezultati kažejo, da vzgojiteljice in pomočnice vzgojiteljic $v$ glavnem poznajo pravilne ukrepe $v$ primeru bolezni in akutnih poškodb, pri tem pa obstaja nekaj izjem. $V$ zvezi z boleznimi in akutnimi poškodbami je bilo med anketiranimi ugotovljeno dobro znanje o primernih ukrepih, a ne pri vseh boleznih in stanjih. Anketirane vzgojiteljice in pomočnice vzgojiteljic so dobro seznanjene z osnovnimi higienskimi ukrepi za preprečevanje nastanka bolezni. Rezultati testa $\mathrm{X}^{2}$ kažejo nekatere statistično značilne povezave pri starosti anketirancev, poklicu (vzgojiteljica ali pomočnica) in delovnih izkušnjah.

Razprava. V vrtcu lahko hitro pride do bolezni ali poškodb, saj so otroci ranljivejša skupina, zato morajo vzgojiteljice in pomočnice vzgojiteljic znati pravilno ukrepati. Poudarjen je pomen dopolnilnega usposabljanja med delavci $v$ vzgojno-izobraževalnih ustanovah, kamor sodijo tudi vrtci. 


\section{INTRODUCTION}

In 2011 , there were approximately 125,000 preschool children in Slovenia, representing about $6 \%$ of the population. The country has one of the highest levels of employed mothers in Europe; consequently, $75 \%$ of children attend kindergartens. The level of inclusion of children in kindergartens increases with children's age. Among the youngest children, $40 \%$ attend kindergarten; among those aged from four to five years, the percentage is over $90 \%$ (1).

Preschool children have significant health problems that are connected with growth and development specialities, and their way of life, which have an influence on their physical, mental, spiritual and social health(2). They are particularly at risk for harming themselves through their activities while playing games, learning and acquiring new experiences. As in other European countries, the most frequent causes of death among children in Slovenia are injuries and poisonings $(3,4)$. They are also more prone to some diseases, their bodies are more vulnerable to harmful environmental effects, and their immune systems have yet not fully developed(5). Admission to kindergarten can increase vulnerability, because children are exposed to new environmental influences. The strategy of the government of the Republic of Slovenia for children's health, related to the environment for the period 20122020 , stresses the importance of protecting the health of children against harmful environmental factors, and sees itan integral part of public health in environmental policy. The policy also set out the priority areas to further reduce the environmental burden in children to improve their health and well-being. At the macro level, this policy highlights the importance of health protection in the kindergarten environment (5).

The United Nation's Declaration of the Rights of the Child (6) states that every child has the right to live and grow up in healthy conditions. The best interests of a child should guide everybody responsible for their education and upbringing, especially their parents. Considering the high percentage of children included in kindergartens and the fact that children in developed parts of the world increasingly spend time in day care institutions, there is an immense responsibility placed on kindergarten teachers (KTs) and kindergarten teacher assistants (KTAs). The problems of injury and illness are always present. The authors of different studies have emphasized these problems (7-9).

The treatment in case of injury or illness in kindergartens and the responsibilities of KTs in Slovenia are defined in the Law on Kindergartens (10), as well as in The Book of Rules and Conditions for Performing Preschool Education (11). Giving first aid in case of injury or illness in a kindergarten is also defined by The Law on Safety in Traffic (12), the Book of Rules about Organization, Material and Equipment for First Aid at Workplace (13) and others. Based on the Law on Kindergartens, the principal of every kindergarten issues the Book of Rules on the Safety of Children, in which procedures, arrangements, treatments, and activities pertaining to children's safety, health, life and well-being in the kindergarten are defined. Each kindergarten must have its own Kindergarten Plan for Acting in Emergency Situations and Unexpected Illness Symptoms. In this plan, individual responsibilities and duties for acting in an emergency as well as providing conditions for appropriate actions are described. All employees have to confirm (by signature) that they are acquainted with the rules of acting in accordance with the plan (14).

From the abovementioned laws and regulations, it can be seen that knowledge of basic hygienic measures and steps for preventing injuries and illnesses, as well as recognition of infectious diseases and knowledge of first aid are expected from KT and KTA. To gain such skills, continuous life-long learning is necessary, in addition to any formal training received when studying, because the characteristics of diseases, kinds of chronic diseases and guidelines for acting in case of injuries are changing. The purpose of this investigation was to determine the level of knowledge of KT and KTA of various themes regarding children's health. The research also determines their knowledge of health principles.

\section{METHODS}

Out of 289 kindergartens in Slovenia, there were 45 randomly selected and sent a questionnaire with 17 questions regarding health. This questionnaire was prepared for KT and KTA. Over the course of two weeks, about $80 \%$ of the kindergartens returned completed questionnaires ( $N=774)$, which included $426(54.6 \%) \mathrm{KTs}$ and 351 (45.4\%) KTAs. The health themes are as follows: kindergarten teachers and their assistants' responsibilities related to health principles, celiac disease, diabetes, febrile seizures, hygiene principles, first aid principles and their opinions pertaining their own knowledge.

The demographic data collected included age, gender, years of experience working with children, and the occupation of a participant.

The survey was pretested in a group of $30 \mathrm{KTs}$ and KTAs for accuracy and ease of administration, in order to identify problematic questions and alter them appropriately.

The analysis was performed in SPSS 17.0, using descriptive methods and nonparametric $x^{2}$ tests. The level of statistical significance was determined as $p<0.05$. 


\section{RESULTS}

The demographic data of 774 participants are presented in Table 1. Our sample included $54.6 \%$ of KTs and $45.4 \%$ KTAs. On average, KTs were older $(42 \pm 10.2)$ than KTAs

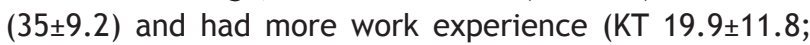
KTA 9.3 \pm 9.2 ).

The share of KTs and KTAs who consider their knowledge of health principles to be very good or excellent is $67 \%$; $30 \%$ deem it to be good (Table 2). Their estimation of first aid knowledge is worse: $45 \%$ consider it very good or excellent and $45 \%$ see it as good. Most of their knowledge (almost one half) was obtained in college or at their faculty. The data about the most recent participation in education on health principles show satisfactory results. All respondents had participated in it less than five years ago; $80 \%$ one year or less ago.
Table 1. Demographic data of research participants expressed as meaningful (S.D. or \%) and [range].

\begin{tabular}{lccc}
\hline & Number & Age & $\begin{array}{c}\text { Work } \\
\text { experience }\end{array}$ \\
\hline KT & $423(54.6 \%)$ & $42.0( \pm 10.2)[22-59]$ & $19.9( \pm 11.8)[1-40]$ \\
KTA & $351(45.4 \%)$ & $35.0( \pm 9.2)[19-57]$ & $9.3( \pm 9.2)[1-38]$ \\
All & $774(100 \%)$ & $38.9( \pm 10.5)[19-59]$ & $15.3( \pm 12.0)[1-40]$ \\
\hline
\end{tabular}

Table 2. Kindergarten teachers' and their assistants' health knowledge self-evaluation in percentages.

\begin{tabular}{|c|c|c|c|c|c|}
\hline \multirow{3}{*}{$\begin{array}{l}\text { Question } \\
\text { How would you rate your knowledge } \\
\text { of health principles? }\end{array}$} & \multicolumn{5}{|c|}{ Statements (\%) } \\
\hline & insufficient & sufficient & good & very good & excellent \\
\hline & 0.1 & 3.4 & 29.9 & 56.2 & 10.4 \\
\hline \multirow{2}{*}{$\begin{array}{l}\text { How would you rate your knowledge } \\
\text { of first aid? }\end{array}$} & insufficient & sufficient & good & very good & excellent \\
\hline & 0.7 & 9.0 & 44.9 & 40.6 & 4.8 \\
\hline \multirow[t]{2}{*}{$\begin{array}{l}\text { Where did you gain most of your } \\
\text { knowledge of health principles? }\end{array}$} & $\begin{array}{l}\text { at college or } \\
\text { university }\end{array}$ & at seminars & at work & $\begin{array}{l}\text { books, } \\
\text { internet }\end{array}$ & elsewhere \\
\hline & 46.0 & 12.5 & 9.8 & 5.4 & 2.3 \\
\hline \multirow[t]{2}{*}{$\begin{array}{l}\text { When did you have the last training } \\
\text { on health principles? }\end{array}$} & $\begin{array}{l}1 \text { year } \\
\text { or less ago }\end{array}$ & $\begin{array}{l}\text { 1-5 years } \\
\text { ago }\end{array}$ & $\begin{array}{l}5-10 \text { years } \\
\text { ago }\end{array}$ & $\begin{array}{l}\text { 10-15 years } \\
\text { ago }\end{array}$ & $\begin{array}{c}\text { more than } 15 \\
\text { years ago }\end{array}$ \\
\hline & 81.6 & 18.4 & 0.0 & 0.0 & 0.0 \\
\hline
\end{tabular}

KTs and KTAs are well aware of the importance of health knowledge in their work with children. As many as $87 \%$ strongly agree and $13 \%$ agree that it is important. If we combine this percentage, we see that all teachers are inclined to agree with the statement about the importance of health knowledge. Most (97\%) know that they have to inform the headmaster and parents in case of a child's acute illness. Teachers have greater difficulty in knowing whether they may accompany a child to a doctor when an emergency arises. Over one half knows they may do so, while $18 \%$ think they have to ask child's parents (Table 3 ). 
Table 3. Kindergarten teachers' and their assistants' responsibility related to health principles in percentages.

\begin{tabular}{lcccc}
\hline \multicolumn{1}{l}{ Question } & \multicolumn{3}{c}{ Statements (\%) } \\
\hline $\begin{array}{l}\text { Is knowledge of health principles } \\
\text { important for KT and KTA? }\end{array}$ & strongly agree & agree & do not agree & definitely do not agree \\
\hline $\begin{array}{l}\text { Is it true that, in case of acute illness, } \\
\text { KT or KTA must inform kindergarten } \\
\text { headmaster and parents? }\end{array}$ & never & only for children aged & only if & always \\
& 2.9 & 3 years or less & a child allows & \\
\hline $\begin{array}{l}\text { Is it true that, in case of emergency, } \\
\text { KT or KTA is not allowed to accompany } \\
\text { a child to a doctor? }\end{array}$ & $\begin{array}{c}\text { true, a child can } \\
\text { be accompanied } \\
\text { only by parents }\end{array}$ & $\begin{array}{c}\text { true, if the } \\
\text { headmaster allows }\end{array}$ & $\begin{array}{c}\text { true, if the } \\
\text { parents allow }\end{array}$ & $\begin{array}{c}\text { not true, a child } \\
\text { can be accompanied } \\
\text { by KT or KTA }\end{array}$ \\
\hline
\end{tabular}

Regarding some diseases and acute injuries, KT and KTA mainly show good knowledge of appropriate measures, but not with all injuries and conditions (Table 4). Almost all of them, 98\%, know that a child with celiac disease mostly only eats gluten-free food. They would give a feverish child a glass of water and call the parents (83\%), as required in the guidelines. Almost all KTs and KTAs (97\%) know the symptoms of diabetes complications; 8 out of 10 can give an appropriate first aid in case of an arm abrasion. Half of KTs and KTAs have already given an antibiotic.

Table 4. Kindergarten teachers' and their assistants' knowledge of health principles in percentages.

\begin{tabular}{|c|c|c|c|c|c|}
\hline Question & & & Statements (\%) & & \\
\hline \multirow[t]{2}{*}{$\begin{array}{l}\text { A child in a group has celiac disease. } \\
\text { What is the correct measure? }\end{array}$} & $\begin{array}{l}\text { In case of a } \\
\text { birthday party, I } \\
\text { would give him/ } \\
\text { her only a small } \\
\text { piece of cake }\end{array}$ & $\begin{array}{l}\text { The child has } \\
\text { a diet, but at } \\
\text { breakfast } \\
\text { he/she can have } \\
\text { one-quarter of } \\
\text { a roll }\end{array}$ & $\begin{array}{l}\text { Only gluten } \\
\text { free food } \\
\text { is permissible }\end{array}$ & $\begin{array}{l}\text { In kindergarten, } \\
\text { we do not account } \\
\text { for the diets of } \\
\text { children }\end{array}$ & I do not know \\
\hline & 0.3 & 0.0 & [98.3] & 0.3 & 0.0 \\
\hline \multirow[t]{2}{*}{$\begin{array}{l}\text { How would you react in case of high } \\
\text { fever }\left(>38.5^{\circ} \mathrm{C}\right) \text { ? }\end{array}$} & $\begin{array}{l}\text { I would take him/ } \\
\text { her immediately } \\
\text { to the doctor }\end{array}$ & $\begin{array}{l}\text { I would call the } \\
\text { parents }\end{array}$ & $\begin{array}{l}\text { I would separate } \\
\text { the child from } \\
\text { the class and } \\
\text { wait for parents } \\
\text { to come }\end{array}$ & $\begin{array}{l}\text { I would } \\
\text { check body } \\
\text { temperature, } \\
\text { give some water } \\
\text { and call parents }\end{array}$ & I do not know \\
\hline & 0.1 & 15.5 & 1.4 & [82.9] & 0.1 \\
\hline \multirow[t]{2}{*}{$\begin{array}{l}\text { Which are the signs of diabetes } \\
\text { complications? }\end{array}$} & $\begin{array}{l}\text { High body } \\
\text { temperature }\end{array}$ & $\begin{array}{l}\text { Incontinence } \\
\text { disorders }\end{array}$ & Chest pain & $\begin{array}{l}\text { Fatigue, } \\
\text { drowsiness, } \\
\text { hunger, thirst, } \\
\text { shivering }\end{array}$ & I do not know \\
\hline & 0.1 & 0.0 & 0.1 & 0.3 & 2.5 \\
\hline \multirow[t]{2}{*}{$\begin{array}{l}\text { A child has an abrasion on his/her } \\
\text { hand. What is the first aid? }\end{array}$} & $\begin{array}{l}\text { I would cover } \\
\text { the abrasion } \\
\text { with a clean pad }\end{array}$ & $\begin{array}{l}\text { I would first } \\
\text { wash the abrasion } \\
\text { with water and } \\
\text { then cover with } \\
\text { a clean pad }\end{array}$ & $\begin{array}{l}\text { I would first wash } \\
\text { the abrasion } \\
\text { with alcohol and } \\
\text { then cover with } \\
\text { a clean pad }\end{array}$ & $\begin{array}{l}\text { I would call } \\
\text { emergency } \\
\text { medical services } \\
\text { immediately }\end{array}$ & I do not know \\
\hline & 0.1 & 0.0 & 0.1 & 0.3 & 2.5 \\
\hline
\end{tabular}




\begin{tabular}{|c|c|c|c|c|c|}
\hline Question & & & tatements & & \\
\hline \multirow{2}{*}{$\begin{array}{l}\text { Have you ever been in a situation } \\
\text { when parents brought antibiotics in } \\
\text { the kindergarten and asked you to } \\
\text { give them to their child at a certain } \\
\text { time? }\end{array}$} & Yes & No & $\begin{array}{l}\text { I do not } \\
\text { remember }\end{array}$ & I & I \\
\hline & 40.1 & [49.5] & 10.4 & & \\
\hline
\end{tabular}

Note: Correct answers are in brackets.

Regarding febrile convulsions (Table 5), KTs and KTAs mostly agreed that they should cool down the child (78\%), call emergency medical services (74\%), and give medicine against fever, provided they had previously obtained a written authorization to do so (86\%). $40 \%$ of respondents agreed that they could give medicine against fever convulsions, although the previously obtained written authorization to do so was not included in the statement.

The results also show that kindergarten professionals are familiar with hygiene principles. More than twothirds state that hand washing is necessary after using the toilet, using toys, touching ones' nose and before meals. However, about half believe that hand washing is not so vital after using books (51\%) or after shaking hands (45.1\%).
Since contagious diseases are common among children, preventive measures represent the basis for infection control. All stated measures are particularly valuable for infection control. Room ventilation, disinfection of toys, sneezing and coughing into one's sleeve are all part of good hygiene practice in kindergartens; it can be confirmed that KTs and KTAs are very familiar with such practices (Table 5). The results also show that kindergarten professionals believe that hand disinfection is a preventive measure (81.3\%). However, hand disinfection is not a preventive measure in kindergarten due to microbial resistance; therefore, this measure is only for health care services.

Table 5. Kindergarten teachers' and their assistants' responsibility related to health principles in percentages.

\begin{tabular}{|c|c|c|c|}
\hline \multicolumn{4}{|c|}{ In a kindergarten, a child has febrile seizures. How would you react? } \\
\hline \multirow[t]{2}{*}{ Answers } & \multicolumn{3}{|c|}{ Statements (\%) } \\
\hline & Agree & Disagree & I do not know \\
\hline I would immediately give the child a medication to treat fever & 40.1 & [49.5] & 10.4 \\
\hline I would cool down the child's body & {$[78.4]$} & 15.3 & 6.1 \\
\hline I would immediately take the child to the doctor & 28.2 & {$[58.0]$} & 13.7 \\
\hline $\begin{array}{l}\text { I would give the child a medication to treat fever only in case } \\
\text { of previously written authorisation }\end{array}$ & {$[86.4]$} & 8.9 & 4.7 \\
\hline I would call the emergency service & {$[74.0]$} & 18.0 & 8.0 \\
\hline \multicolumn{4}{|c|}{ How important is hand washing for infection prevention? } \\
\hline After toilet use & {$[95.5]$} & 0.0 & 0.5 \\
\hline Before a meal & {$[99.2]$} & 0.1 & 0.6 \\
\hline After shaking hands & {$[53.1]$} & 45.1 & 1.8 \\
\hline After touching one's nose & {$[90.5]$} & 8.5 & 0.9 \\
\hline After using toys & {$[86.7]$} & 12.4 & 0.9 \\
\hline After using books & {$[47.3]$} & 51.0 & 1.7 \\
\hline
\end{tabular}




\begin{tabular}{|c|c|c|c|}
\hline \multicolumn{4}{|c|}{ How important are the following infection preventive measures? } \\
\hline \multirow[t]{2}{*}{ Answers } & \multicolumn{3}{|c|}{ Statements (\%) } \\
\hline & Agree & Disagree & I do not know \\
\hline Sneezing /coughing into a sleeve & [96.9] & 2.5 & 0.7 \\
\hline Hand washing after touching animals & [96.4] & 3.1 & 0.5 \\
\hline Separation of a sick child from the rest of the group & [92.5] & 5.6 & 1.9 \\
\hline Hand disinfection & 81.3 & [17.7] & 1.0 \\
\hline Preventive vaccination & [74.4] & 20.6 & 4.9 \\
\hline Disinfection of toys & [97.7] & 2.2 & 0.1 \\
\hline Ventilation of rooms & [99.7] & 0.1 & 0.1 \\
\hline
\end{tabular}

Note: Correct answers are in brackets.

The $x^{2}$ test has shown there are statistically significant associations between the age of teachers and their assistants and the choice of whether they accompany a child to the doctor in case of emergency. The results show respondents would accompany a child to the doctor in the age group from 40 to 50 years in $32 \%$, followed by the age group from 30 to 40 years (28\%), the age group of $<30$ years $(21 \%)$ and of $>50$ years $(19 \%)$. Furthermore, there are statistically significant associations regarding their reaction to a child having a high fever, where only $17 \%$ of respondents in the age group of $>50$ years would check the child's body temperature, give heror him some water and call their parents. In the age group of $<30$ years, this would be done by $26 \%$ of respondents, $29 \%$ in the age group of 30 to 40 years, and $28 \%$ in the age group from 40 to 50 years. With regard to occupation, $58 \%$ of KTsand $42 \%$ of KTAs would monitor temperature and prevent dehydration. Results of our study also show that KT and KTA often face the situation when parents brought antibiotics in the kindergarten and asked to administer them. In the age group of $<30$ years, $18 \%$ of respondents are faced with this kind of situation, $22 \%$ in the age group from 30 to 40 years, $27 \%$ in the age group from 40 to 50 yearsand $33 \%$ in the age group of $>50$ years. Similar findings are related to the work experiences where respondents $<10$ years of work experiences were asked to administer antibiotics in $33 \%$ and those with $>10$ years of work experiences in $67 \%$. Results also show that KTs are often asked to provide antibiotics for children (65\%) in comparison to KTAs (35\%). Statistically significant association was found between the age and last training in health principles, where in the age group of $<30$ years, $23 \%$ attended training in the last year, in the age group from 30 to 40 years $28 \%$, in the age group from 40 to 50 years $30 \%$, and $19 \%$ of $\mathrm{KT}$ and KTAs aged $>50$ years (Table 6 ).

Table 6. Comparison of kindergarten teachers' and their assistants' answers regarding the age, work occupation and years of work experiences.

\begin{tabular}{|c|c|c|c|c|c|c|c|}
\hline & & \multicolumn{6}{|c|}{ Statistics } \\
\hline \multicolumn{2}{|c|}{ Questions } & \multicolumn{2}{|c|}{ Age } & \multicolumn{2}{|c|}{ Occupation } & \multicolumn{2}{|c|}{ Work experiences } \\
\hline & & p-value & sig. & p-value & sig. & $p$-value & sig. \\
\hline \multirow{3}{*}{ 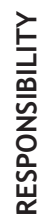 } & Knowledge of health principles is important for KT and KTA & 0.913 & NS & 0.222 & NS & 0.791 & NS \\
\hline & $\begin{array}{l}\text { Is it true that, in case of acute illness, KT or KTA must inform the } \\
\text { kindergarten headmaster and parents? }\end{array}$ & 0.319 & NS & 0.992 & NS & 0.793 & NS \\
\hline & $\begin{array}{l}\text { Is it true that, in case of emergency, KT or KTA should not } \\
\text { accompany the child to the doctor? }\end{array}$ & 0.000 & $* *$ & 0.459 & NS & 0.984 & NS \\
\hline
\end{tabular}




\begin{tabular}{|c|c|c|c|c|c|c|c|}
\hline \multirow{3}{*}{\multicolumn{2}{|c|}{ Questions }} & \multicolumn{6}{|c|}{ Statistics } \\
\hline & & \multicolumn{2}{|c|}{ Age } & \multicolumn{2}{|c|}{ Occupation } & \multicolumn{2}{|c|}{ Work experiences } \\
\hline & & p-value & sig. & p-value & sig. & p-value & sig. \\
\hline \multirow{6}{*}{ 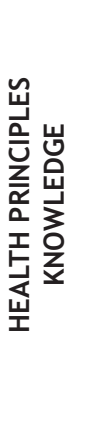 } & A child in the group has celiac disease. What is the correct measure? & 0.465 & NS & 0.411 & NS & 0.611 & NS \\
\hline & How would you react in case of high fever $\left(>38.5^{\circ} \mathrm{C}\right)$ ? & 0.000 & ** & 0.000 & ** & 0.869 & NS \\
\hline & Which are the signs of diabetes complications? & 0.008 & * & 0.890 & NS & 1.000 & NS \\
\hline & A child has an abrasion on his/her arm. What is the first aid? & 0.764 & NS & 0.960 & NS & 0.180 & NS \\
\hline & $\begin{array}{l}\text { Is it advisable to continue breastfeeding when a child is oneyear old } \\
\text { and goesto the kindergarten? }\end{array}$ & 0.619 & NS & 0.002 & * & 0.504 & NS \\
\hline & $\begin{array}{l}\text { Have you ever been in a situation when parents brought antibiotics } \\
\text { to the kindergarten and asked you to give them to the child at a } \\
\text { certain time? }\end{array}$ & 0.000 & $* *$ & 0.000 & ** & 0.000 & ** \\
\hline \multirow{3}{*}{ 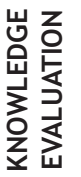 } & How would you rate your knowledge of health principles? & 0.708 & NS & 0.829 & NS & 0.166 & NS \\
\hline & Where did you gain most of your knowledge of health principles? & 0.010 & * & 0.773 & NS & 0.422 & NS \\
\hline & When did you have your last training in health principles? & 0.000 & ** & 0.547 & NS & 0.694 & NS \\
\hline
\end{tabular}

Legend: * statistical significance $p<0.05$; ${ }^{* *}$ strong statistical significance $p<0.001$; NS not statistically significant

\section{DISCUSSION}

Life-long education is becoming increasingly important. Supplementary education is necessary among skilled workers in educational institutions, including kindergartens. Because children are a vulnerable population group, teachers can encounter injuries and sudden illnesses at work. The first aid guidelines state that, in such cases, a quick and appropriatesequence of action is necessary (15). To fulfil these demands, KTs and KTAs are extremely well aware that at least a minimum level of knowledge is required. The results show that they attribute immense significance to such knowledge, as only $0.1 \%$ do not agree with the statement that the knowledge of health principles is important if one works with children. Self-evaluation of their knowledge on health principles confirms their awareness about its significance; most frequently, the respondents estimate it as very good, 4 (on the level 1-5; 5 is the highest grade). The self-evaluation of their first aid knowledge is worse; most frequently, they deemed it to be 'good', i.e. level 3. Most of their knowledge was obtained in school (almost one half). Especially intriguing were data regarding the most recent education on health principles: all respondents participated in such training less than five years previously, with $80 \%$ attended such training one year or less ago.

Recommendations for managing cases of emergency and sudden illness symptoms in kindergartens (14) state that it is necessary to call emergency services in life-threatening situations (112), and afterwards, inform the parents as soon as possible. The person who has given first aid accompanies the child to a medical institution and then waits there until the parents or guardians arrive. KTs and KTAs know the first part (calling emergency services) very well $(97 \%)$, but only a half $(51 \%)$ of them know that the person who has given first aid has to accompany the child to a medical institution. From the data of other research in Slovenia (16), we can assume that also teachers (all stated $>90 \%$ recognition) know very well the emergency number (112).

It is not necessary, in some cases, to take a child to a doctor immediately, although it is necessary to give the child appropriate first aid. In case of an abrasion onchild's arm, $85 \%$ of respondents would properly take care of it by rinsing it with water and applying sterile coverage and bandages as dictated by the guidelines (17). The results of a similar research proved that skilled workers in kindergartens are theoretically qualified to give first aid in the case of non-life-threatening injuries, such as abrasions, scratches and minor burns. Less than $30 \%$ of respondents would take proper measures in case of unconsciousness, cardiac arrest, poisoning or suffocation, in accordance with the valid first aid practices (18). Based on the analysis of 117 documented injuries, for almost half of which medical care was required, Rok Simon (9) found that first aid given by 429 pedagogical workers was adequate only in half of the cases. Parents' first aidgiven to their children was poor: only $10 \%$ of questioned parents would use proper methods to remove a foreign body obstruction in the airway of their suffocating child (19). When giving first aid to an unconscious child, only $9.5 \%$ 
of respondents would first check responses (20). It has been shown that parents know how to act properly in circumstances that happen most frequently with their children and which could be sometimes fatal for the child (21). Neither Slovenian nor foreign (USA) parents are sufficiently educated in giving first aid to their children or in taking care of their children's wounds and burns (22).

In addition to injuries, kindergarten teachers deal with the increasing phenomenon of various chronic diseases, such as celiac disease and diabetes. While celiac disease was relatively rare some years ago, the latest research from around the world has shown that there is at least one patient for every 100 inhabitants (23). This means that about 20,000 people in Slovenia could have celiac disease. The latest data for Slovenia show that the typical kind of celiac disease in children occurs with the frequency of $2 / 1000$ (24). Celiac disease is systematic immune condition disease that most often affects the small intestine. The disease reacts to the consumption of gluten, so patients are obliged to follow a gluten-free diet for the rest of their lives. KTs know this very well; 98\% would not give an afflicted child food containing gluten.

Similarly, every year in Slovenia, more children fall ill with diabetes. The prevalence of type 1 diabetes among children increases by almost $4 \%$ annually (25). In case of diabetes complications, there are guidelines how to act, but one must be able to recognize the complications. Characteristic signs of hypoglycaemia are fatigue, drowsiness, hunger, thirst, shivering (15). A total of $97 \%$ of teachers correctly cited these. In Slovenia, the Department of Endocrinology, Diabetes and Metabolic Diseases at the University Children's Hospital Ljubljana, is the national centre for childhood diabetes, where teachers can gain knowledge about diabetes. Many teachers and other caregivers came annually to learn about diabetes in a one-day course (26). Besides the teachers, also children's parents play a crucial role in helping children with diabetes integrate into a new, kindergarten environment. In collaboration with the National Centre for Childhood Diabetes, Association for Children with Metabolic Disorders and Franciscan Family Institute, a parent support group was designed to provide psychosocial support for parents of children with diabetes. The group turned out to be a promising supportive, therapeutic and psychoeducational space. Effective psychosocial support to families is a part of integrative healthcare for children and adolescents with diabetes $(27,28)$.

Some disease conditions, including chronic conditions, require treatment with medication. About half of KTs and KTAs had been in a situation in which parents brought medicationto kindergarten (antibiotics), but we do not have the data as to whether they enclosed instructions and doctor's permission to administer the medicine. Results of statistical analysis show that KTs in the age group of $>50$ years, those with working experiences of $>10$ years, are more often faced with this situation than their younger and less experienced colleagues. As a rule, drugs should not be administered in the kindergarten. In exceptional cases, a medication may be given, for example, for a fever, but it is necessary to have parents' or guardians' previously written permission. KT and KTA could give a child a glass of water in case of fever and call parents (83\%), as instructed in guidelines. The questionnaire did not give a teacher the opportunity to choose the possibility of administering drugs to a child with fever. In case of a known illness or the worsening of a chronic disease, such as febrile convulsions or asthma, it is necessary to have parents' or guardians' previously obtained written permission, as well as doctor's permission to administer the medicine and instructions on administering the medicine (14). In the hypothetical case of a child with febrile convulsions, teachers indicated agreement with statements about correct measures. As the guidelines indicate, they would cool down the child $(78 \%)$, call urgentmedical help $(74 \%)$ and administer medicine against fever, provided they had previously obtained written permission (86\%); $40 \%$ of respondents said that they would administer medicine for febrile convulsions, although they made no mention of written permission to administer medicines.

We found that KTs and KTAs are familiar with the principles of hand washing. Most stated that hand washing is necessary after toilet use, before meals, after touching one's nose, and after playing with toys. Wong et al. (29) determined that a teacher's perception of risk increases after an outbreak of an infectious disease. Another study showed that one of the protective factors for handfoot-mouth disease in kindergartens is hand washing (30). Our study showed that KTs and KTAs are familiar with the principles of hygiene and disease prevention, except regarding hand disinfection: $80 \%$ of respondents believe that this is a valuable preventive measure in kindergartens.

Based on the statistical analysis, we can indicate statistical characteristics with regard to age, occupation and work experiences. The results show significant differences $(p<0.05)$ concerning the age of respondents and their choice of whether or not they would accompany a child to a doctor in case of emergency. In the age group from 40 to 50 years, $32 \%$ of KTs and KTAs would do so, whereasin the age group from 30 to 40 years $28 \%$ of KTs and KTAs would do so, followed by the age group of $<30$ years in $21 \%$ and $>50$ years in $19 \%$. Moreover, there are statistically significant differences among age groups regarding their reaction to high fever, where in the age group $<30$ years this would be done by $26 \%$ of respondents, $29 \%$ in the group from 30 to 40 years, $28 \%$ in the group from 40 to 50 years and only $17 \%$ of respondents in the age group $>50$ years. 
Our study is a significant contribution to the understanding of the importance of health education, since we found that age, occupation and years of working experience have no influence $(p>0.05)$ on how KTs or KTAs would take care of children with celiac disease and give first aid for abrasions, and whether they would informa headmaster and parents. Nevertheless, we recognised that antibiotics are still a relevant topic and should be studied in the future.

\section{CONCLUSIONS}

KTs and KTAs are well aware of the importance of being familiar with health principles for children's safety in kindergartens. Kindergarten teachers and their assistants take part in frequent trainings in the principles of healthy ways of life. Therefore, it is understandable that they have evaluated their knowledge rather highly. However, according to their evaluations, their knowledge of basic first aid is rather low. We propose that it would be necessary also to include first aid topics in the on-the-job training, especially in view of recent changes to guidelines for resuscitation.

About half of the respondents stated that most of their knowledge about healthy way of living theyacquired during their schooling. This raises questions regarding current students, as the Bologna Process has eliminated health education from the curriculum. In view of the increase of chronic diseases among children and the frequency of injuries, knowledge about correct measures in such cases will become even more necessary.

\section{ACKNOWLEDGEMENTS}

The authors wish to thank all the participants who took part in the anonymous questionnaire.

\section{CONFLICTS OF INTERESTS}

The authors declare that there is no conflict of interest.

\section{ETHICAL APPROVAL}

The kindergartens included in the research were randomly selected and sent the questionnaire. The questionnaire was anonymous and kindergarten staff could choose whether or not to participate in the research.

\section{FUNDING}

This work was funded by the University of Ljubljana, the Faculty of Health Sciences.

\section{AUTHORS' CONTRIBUTION}

All authors were involved in the development of the project, study design, data collection and its interpretation. All authors contributed to the preparation of the manuscript and approved the final version of the text.

\section{REFERENCES}

1. Statistical Office of the Republic of Slovenia. Kindergartens, detailed data, Slovenia, school year 2012/13 - final data. Available Sept 20, 2013 from: http: //www.stat.si/novica_prikazi.aspx?id=4578.

2. World Health Organisation. Pocket book of hospital care for children: guidelines for the management of common childhood illnesses. 2nd ed. Geneva: WHO Press. Available Sept 23, 2014 from: http:// apps.who.int/iris/bitstream/10665/81170/1/9789241548373_eng. pdf?ua=1.

3. European Child Safety Alliance. Child safety report card 2012: Europe summary for 31 countries. Birmingham: European Child Safety Alliance, Eurosafe. Available Sept 22, 2012 from: http:// www.childsafetyeurope.org/publications/info/child-safety-reportcards-europe-summary-2012.pdf.

4. Rok Simon M. Injuries of children and adolescents: analysis of mortality and morbidity. Ljubljana: National Institute of Public Health, 2007.

5. Government of the Republic of Slovenia. Strategija Republike Slovenije za zdravje otrok in mladostnikov $v$ povezavi $z$ okoljem 2012-2020. Ljubljana, 2011. Available Sept 5, 2013 from: http:// www.mz.gov.si/uploads/media/strategija_zdravje_otrok_040212. pdf.

6. The United Nations Declaration on the Rights of the Child, 1959. Available Nov 27, 2014 from: http: / / www.unicef.org/malaysia/1959Declaration-of-the-Rights-of-the-Child.pdf.

7. Eberl R, Schalamon J, Singer G, Ainoedhofer H, Petnehazy T, Hoellwarth ME. Analysis of 347 kindergarten-related injuries. Eur J Pediatr 2009; 168: 163-66.

8. Videmšek M, Štihec J, Karpljuk D, Meško M. Children's injuries in locomotor / sport activities in kindergarten. Sod Pedag 2009; 60(Suppl 3): 126-39.

9. Rok Simon M. Injuries of children in two kindergartens in Ljubljana in 1999. Zdrav Var 2002; 41: 309-14.

10. Law on kindergartens, Ur L RS 25/2008.

11. The book of rules and conditions for performing preschool education. Ur L RS 82/2005.

12. The law on safety in traffic. Ur L RS 25/2006.

13. Book of rules about organization, material and equipment for first aid on workplace. Ur L RS 136/2006.

14. National Institute of Public Health. Recommendations for action in kindergartens at emergencies and sudden illness incurred situations. Ljubljana: National Institute of Public Health, 2011.

15. International Federation of Red Cross and Red Crescent Societies. International first aid and resusciation guidelines 2011. Geneva: International Federation of Red Cross and Red Crescent Societies, 2011.

16. Slabe D, Medja M. Knowledge of the European number for emergency phone calls. Ujma 2007; 23: 170-5.

17. Nolan JP, Soar J, Zideman AD, Biarent D, Bossaert LL, Deakin C, et al. European resusciation council guidelines for resusciation 2011: section 1: executive summary. Resusciation 2010; 81: 1219-76.

18. Fink R, Slabe D. First aid knowledge in Slovenian kindergarten. In: International Scientific Conference, Solidarity for Social Capital, Portorož, 20-21 October, 2011: 423-30. 
19. Izlakar J, Slabe D. First aid in infant with complete airway obstruction with foreign body: practical knowledge of laymen. In: Razvijanje medpoklicnega sodelovanja $v$ času študija na področju zdravstvenih ved. 3. študentska konferenca s področja zdravstvenih ved. Maribor: Univerza v Mariboru, Fakulteta za zdravstvene vede, 2011: 35-43.

20. Brezavšček J, Peršonja Černe $M$, Karnjuš I. Parental knowledge in child first aid. In: Razvijanje medpoklicnega sodelovanja $v$ času študija na področju zdravstvenih ved. 3. študentska konferenca s področja zdravstvenih ved, 2011. Maribor: Univerza v Mariboru, Fakulteta za zdravstvene vede, 2011: 45-53.

21. KarničnikA. Nujna stanja pri otrocih in prva pomoč staršev: diplomsko delo. Maribor: Univerza v Mariboru, Fakulteta za zdravstvene vede, 2010.

22. Singer AJ, Gulla, J, Thode J, Cronin KA. Pediatric first aid knowledge among parents. Pediatr Emerg Care 2004; 20(Suppl 12): 808-11.

23. Fasano A, Berti I, Gerarduzzi T, Not T, Colletti RB, Drago S, et al. Prevalence of celiac disease in at-risk and not-at-risk groups in the United States. Arch Int Med 2003; 163(Suppl 3): 268-92.

24. Slovensko društvo za celiakijo. O celiakiji, 2011. Available Sept 23, 2013 from: http://drustvo-celiakija.si/o_celiakiji/.

25. Battelino T, Phillip M, Bratina N, Nimri R, Oskarsson P, Bolinder J. Effect of continuous glucose monitoring on hypoglycemia in type 1 diabetes. Diabetes Care 2011; 34(Suppl 4): 795-800.

26. Bratina N, Shalitin S, Phillip M, Battelino T. Type 1 diabetes in the young: organization of two national centers in Israel and Slovenia. Zdrav Var 2015; 54: 139-45.

27. Pate T, Rutar M, Battelino T, Drobnič Radobuljac M, Bratina N. Support group for parents coping with children with type 1 diabetes. Zdrav Var 2015; 54: 79-85.

28. Drobnič Radoljubac M, Shmueli-Goetz Y. Attachment to caregivers and type 1 diabetes in children. Zdrav Var 2015; 54: 126-130.

29. Wong EMY, May MH Cheng, Lo SK. Teachers' risk perception and needs in addressing infectious disease outbreak. JOSN 2010; 26(Suppl 5): 398-406.

30. Zhu L, Chen C, Chen Z. Risk factors of hand-foot-mouth disease in kindergartens in Guangzhou. Chinese J School Health 2012; 10: 10-25. 